\title{
Readiness Factor Identification on Kabupaten Karawang SMEs towards Industry 4.0 Era
}

\author{
Rianita Puspa Sari ${ }^{*}$, Deri Teguh Santoso ${ }^{2}$
}

\begin{abstract}
This study aims to explore the readiness of SMEs Karawang in terms of Technology, Organization, Environment (TOE) Framework and technological readiness (TRI) for benefits of industry 4.0 (BOI) in the dimension of industry 4.0 (DOI), viewed from different business scale groups; micro-businesses (group 1) and small-medium businesses (group 2), with a random sampling of 300 SMEs samples using the multigroup-SEM method. The results showed that the feasibility of the research model was quite good from the results of the structural test of the multigroup-SEM. In the micro business (group 1), managerial (TOE) and technology (TRI) MSME readiness factors influence the use of technology pillars in the industry dimension (DOI). In contrast, in small and medium business groups (group 2), the managerial (TOE) and technology (TRI) readiness of MSMEs influence the use of (DOI) and the benefits of the industrial era 4.0 (BOI).
\end{abstract}

Keywords: Industry 4.0, Readiness, TOE, TRI, BOE, DOI, MSMEs, Karawang.

\section{Introduction}

Industry 4.0 is a terminology deducted from the fourth industrial revolution, which defined as a new level of organization. It controls all value chains in a product life cycle, targeting consumer needs, which are becoming more individual [1]. Initiation of industrial revolution 4.0 is introduced by Germany in 2011, with a concept in information exchange and autonomous machine control for production. Industry 4.0 has been one of the popular topics among the world industry and academy to develop the industry. Four aspects of it are factory, business, product, and consumer. In a business aspect, the presence of Industry 4.0 is to optimize multi-company configuration, suppliers, logistics, resources to the hand of a consumer in real-time. Hence, it is very profitable for the consumer since it provides a new purchase method to obtain the desired product in a fast way and convenient timing, even to change orders without affecting additional costs. This Symptom awakes many countries on the presence of Industry 4.0, e.g., the Chinese government to create a plan on Industry 4.0 development on 2015 that is called "Made in China 2025" [2].

Indonesia plans to enter Industry 4.0 by implementing a strategic roadmap named Making Indonesia 4.0. One of the critical priorities under progress through

\footnotetext{
${ }^{1}$ Faculty of Technology, Industrial Engineering Department, Universitas Singaperbangsa Karawang, Jl. H.S. Ronggowaluyo, Telukjambe Timur, Karawang 41361, Indonesia.

Email: rianita.puspasari@ft.unsika.ac.id

${ }^{2}$ Faculty of Technology, Mechanical Engineering Department, Universitas Singaperbangsa Karawang. Jl. H.S. Ronggowaluyo, Telukjambe Timur, Karawang 41361, Indonesia.

* Corresponding author
}

SMEs (Small and Medium Enterprise) empowerment is to increase Indonesia's competitiveness with other countries through the use of current technology and innovation. SME involvement can affect the Indonesia economy sector that already contributes to $57 \%$ of annual Indonesia GDP, henceforth SMEs empowerment under Making Indonesia 4.0 in 2030 can strengthen the Indonesia economy [3].

According to research by Nugroho, [4], one of several things SME must address to face global competition is on information technology use. Yet, Indonesia has not fully adopted information technology to its full potential, with only $20 \%$ only using computer technology, and $41.4 \%$ has not yet adopted technology to support its business process. This issue is aligned with research from [5] that states the SME's inhibitor factor is the lack of information and SME capability to access the market. Hence according to Sari [6] SMEs stakeholder readiness is needed in 4.0 Industrial era to optimize SME business ability. Its also according to Faller et al. [7] the difficulty in applying Industry 4.0 is caused by SMEs inability to invest in technology and lack of adequate resources. Besides that, referring to research by Suci [8] SMEs has a strong market and has a contribution to Indonesia economic development. Still, SMEs weakness on managerial and operational skills and demand in SME needs implementation readiness through product and service digitization transformation, hence demand in information and Industry 4.0 technological approach is still high $[1,9,10]$.

Technological adoption readiness according to Aboelmaged [11] in SME level can be done through digitization readiness prediction, i.e., Technological 
Readiness Index (TRI) as well as Technological Organization, Environment (TOE) framework. TOE framework is a correct theoretical landscape to investigate digital readiness in technology maintenance and innovation implementation in technological context, organization, and environment.

Fathian et al., [12] identifies technological readiness in SMEs consisting of organization features, information technology availability and communication, infrastructure, and security. This concept in [11] is a TOE measurement framework. Achjari et al., [13] focus on the study of SMEs' readiness. Many of the preliminary researches study on the macro business sector, which can't be implemented in SMEs. Since, SMEs' have unique properties in centralized leadership, hence a greater influence in technological adoption is needed. In this study we used revised TRI index model which is developed by Parasuraman et al. [14] and is aligned with [11].

According to Fathian et al. [12], technological readiness in SME can be identified as SME ability in adopting technology use, as well to leverage technology availability. This statement is aligned with Vaidya [1]. Industry 4.0 implementation focus on human and business process integration, which resulted in continuous improvement, focusing on value. Digital presence benefits according to Tiago et al.[15] is significant to explore as an implication from a shift into a digital dimension that transfers individually to share knowledge, entertainment among each other, and intercultural promotional dialogue. Oesterreich and Teuteberg [16] confirm digitization technology and automation have numerous benefits from an economic perspective in the form of social and technology. Digital dimension and virtualization are one of the technological keys in Industry 4.0 context, specifically in the use of cloud computing, big data, mobile computing, social media, and digitization. Industry 4.0 context needs to be evaluated to map enterprise readiness, one of the ways is using IMPULS Industry 4.0 readiness model, based on Industry 4.0 technology pillar [17].

Suci [8] studied on data phenomena released by BPS in 2016. She showed SMEs have to be continuously mentored to improve growth on GDP on a national level. This statement is in line with Sari et al. [6]. Kab. Karawang SMEs are dominated by young and productive age SME stakeholders. It indicates the ability to adapt and realizes market opportunity and current trends. They need guidance on how to build SMEs industry because a lot of them do not join the SMEs community. Hence an exploration in readiness factor for SMEs in Kab. Karawang from a business group scale, whether it is different, can be one point of reference for stakeholders to guide SMEs effectively on business group scale to improve knowledge and foster Industry 4.0 skills. Appendix 1 shows a complete list of operational variabel used in this research.

SMEs are classified as micro, small, and macro [8], referring to the definition of SMEs by UndangUndang No.20 Pasal 1 Tahun 2008. Pasal 6 on SME criteria, measures on a different group scale can classify SMEs' growth fluctuation. According to [5], the categorization of the SMEs sector has priority means on recognizing patterns and steps on giving information to SMEs on growth improvement. The purpose of this research is to identify SMEs readiness factor in facing 4.0 industrial revolution era in a different business group scale specifically in Kabupaten Karawang, from TOE readiness and TRI against the benefit and technology pillar used in Industry 4.0.

\section{Methods}

This research is explanatory research to extrapolate factor that affects SMEs readiness towards Industry 4.0 era using Multigroup-SEM Methods. MultigroupSEM is designed to identify and explore various groups of the scale of micro-businesses, small businesses, and medium businesses having different readiness or not in the industrial revolution era 4.0.

Data gathering is done through a cross-sectional method with primary data acquisition using questionnaires and interviews. Research permit procedure is addressed through a research permit letter sent to Dinas Kesatuan Bangsa dan Politik (Kesbangpol) Kabupaten Karawang through LPPM Unsika under No. 002/UN64.10/PP/2019, which followed by the publication of recommendation letters form Kesbangpol under No. 070.1/243/KSBAM/2019.

Interviews were conducted on Dinas UMKM to classify the SME group as well as the quantity of SME groups in Kab. Karawang. Based on an interview result in 2019, there were 41.809 known SMEs in Kab. Karawang, the number increased by $6.9 \%$ compared to LPPM Unsika data in 2015 [18] with a quantity of 38.904 SMEs.

\section{Population and Sample}

The population in this study was the SMEs in Kab. Karawang as many as 41,809 SMEs. The sampling technique used in this study is quota sampling. Quota sampling is the second type of purposive sampling. This sampling technique ensures that certain groups are adequately represented in the study by assigning a quota fixed for each subgroup based on the total numbers of each group in the population [19]. The rule of thumb for multigroup-SEM, for each group we need at least 100 respondents [20]. In this study, there are three groups. According to that rule of thumb, this study requires 300 (3 groups x 100 respondents) samples of respondents. 
Data collection was assisted by 2 students as survey officers. The districts within the distribution of the questionnaire were Kecamatan Cilamaya Wetan, Cilamaya Kulon, Cikampek, Kota Baru, Banyusari, Jatisari, Tirtamulya, Purwasari, Klari, Telagasari, Lemah Abang, Rawamerta, Pedes, Cilebar, Tempuran, Kutawaluya, Karawang Timur, Karawang Barat, Rengasdengklok, Ciampel, Telukjambe Timur, Telukjambe Barat, Pangkalan dan Tegalwaru.

Preliminary questionnaires were distributed to 300 SMEs in Karawang Regency directly by visiting the SMEs address obtained from Dinas UMKM starting in April 2019 until May 2019. After the data were recapitulated, we found among 100 respondents, 90 of them have micro-scale businesses. In comparison, ten small scale respondents. Hence the second and third stages of data collection are needed to be assisted by the Dinas UMKM from June to July 2019; 128 data respondents are collected. Data collection is carried out in stage 4 with Apindo (Indonesian Employers' Association) in August-September and received 72 respondents, bringing the total data collection to 300 respondents.

\section{Results and Discussions}

\section{Respondent Profile}

The result from the questionnaire distributed to SMEs owners, $60 \%$ of owners are women, and they are in the productive age of 21-30 years old. Most SMEs did not join any communities or organizations ( $46 \%$ ), and only $26 \%$ are actively participating. Based on the value of their assets, $62 \%$ are micro SMEs. Referring to UU no. 20 Tahun 2008, 66\% of SMEs are considered micro based on their sales. Research on Industri 4.0 technologies and concepts in the practical publication by [16] is used to measure SMEs' technology usage. The result shows that $78 \%$ of the respondent has used industry 4.0 technology, where $56 \%$ of it through social media, $47 \%$ mobile computing, $13 \%$ cloud computing, $9 \%$ digitization, and only $2 \%$ use big data. Therefore, most SMEs in Kab. Kerawang uses social media in their business. Technology has been used in the last three years by $73 \%$ of respondents. Adopting research by [15] on the advantage of industry 4.0 technology, $76 \%$ SMEs use it to gather information, $66 \%$ productivity improvement, promotion, and customer relationship, and $52 \%$ measure income and cost-saving.

\section{Research Instrument Testing}

Editorial changes in the preliminary questionnaire led to the retrieval of data through the distribution of other questionnaires. The results of the preliminary questionnaire that have been done were not used in this study. The validity and reliability tests were based on the results of the answers of 300 Karawang
Regency SMEs to the questionnaire question items. The research instrument test aims to assess quality research data validity. The test instruments of this research include the normality test, validity test, and reliability test, which is calculated using IBM SPSS Statistics 21 software:

\section{Validity Test}

Validity test is used for the preliminary questionnaire to test the accuracy (valid) of the statement you want to measure in the questionnaire items by comparing the value of $r$-count and $r$-table using the IBM SPSS Statistics 21 program. Data processing for the validity test is calculated based on a comparison of values between r-table and r-count. In this study, it is known that there are 30 samples first with a degree of freedom 28 (dof) and significant a 0.05 (two-tailed). So that it has an r-table value of 0.361 for $r$-count obtained from the SPSS calculation results using data that has been changed to an interval scale.

Validity test can be known to all questionnaire items based on the perception of valid UMKM actors with $r$ count greater than $r$ table (0.361). It is concluded that the indicators on the research instrument have good validity, meaning that each statement item on the indicator has an adequate level of accuracy/accuracy. If all 300 respondents' data is used to test the instrument, SPSS should not be needed anymore, because the SEM output can be used to test validity and reliability, even normality so that most tools are used. Usually, the instrument testing is done using 30 samples first before being used as a whole

\section{Reliability Test}

The reliability test is carried out to test the trust and consistency (reliability) of the question or measuring instrument used. The reliability test is done by looking at the Cronbach alpha value obtained through the help of the IBM SPSS Statistics 21 program, the results of the reliability test show that each indicator item questionnaire question is measured consistently and reliably with a Cronbach's alpha value greater than 0.7. It is concluded that the questionnaire as a tool measuring the research has a good reliability value, meaning that the respondent's answer is consistent with every question in the questionnaire in the study.

\section{Normality Test}

The data normality test in this study aims to test the SEMs data assumptions, using the KolmogorovSmirnov method with the IBM SPSS Statistics 21 program. The purpose is to determine the distribution of data. Based on the normality test using Kolmogorov Smirnov, data has a normal distribution, so the SEM assumption is fulfilled. 


\section{SEM-Multigroup Test}

The CFA Multi-Group Model is a design for overcoming problems in studying various groups/ populations or wanting to know the average value of the factors measured by the instrument or the relationship between different factors between various populations/groups. Multigroup Modeling, applying simultaneous analysis of several groups/ populations, both from different population groups, or mutually exclusive groups, each of which can be defined as categorical variables in one's data. By observing what is observed or measured with the assumption of fixed groups and the number of groups that must be limited. The Multigroup CFA model is often used to test the factorial invariance of the measurement scale. Factorial invariance of the scale consists of two types of invariants: measurement invariance and structural invariance. Invariance measurements are usually tested first, and then structural invariance [20].

CFA model multigroup testing, in this study, used two independent samples selected, namely the micro-scale business group and the small and medium-scale group based on the category of SEMs turnover referring to UU no 20 Tahun 2008. The micro-scale business group (group 1) with a sample of 199 micro-business respondents, while the small and medium-scale group (group 2) of 101 respondents combined from 68 smallscale business respondents, 22 medium business respondents, and 11 large business respondents.

The sample size for a simple CFA model with a 150 for multigroup modeling, or the rule of thumb sample size in a multigroup model is 100 cases/group observations [20]. So that in this study, the sample is considered sufficient to process the data using the multigroup model.

Table 1. Test result baseline model

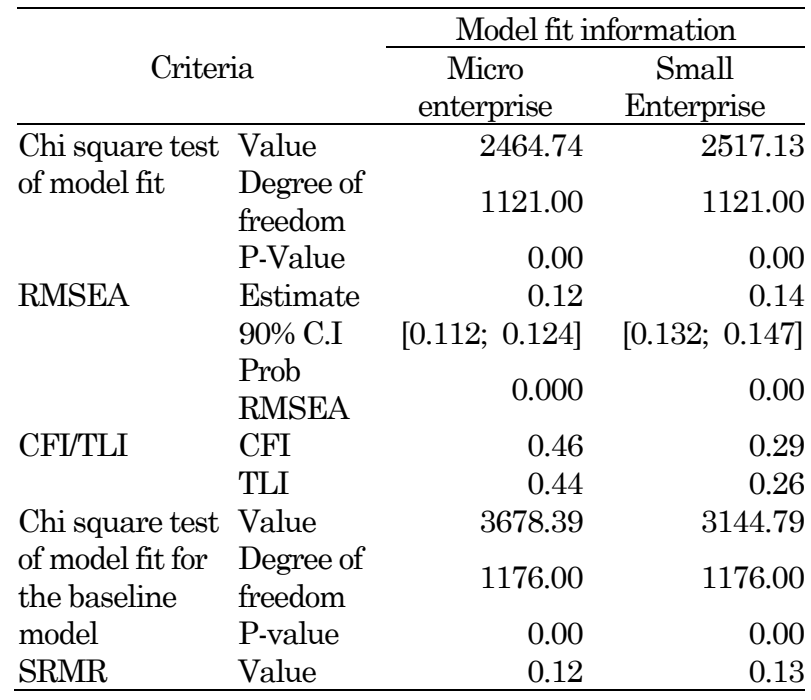

Four dimensions in analyzing the factors of SEMs readiness in the Industrial 4.0 era are TOE (Technology, Organization, Environmental), TRI (Technology Readiness Index), BOI (Benefits of Industry 4.0), DOI (Dimension of Industry 4.0). Each dimension has been measured by several indicators, which can be seen in Appendix 1.

Before testing stage 4 level measurement invariance is carried out. First, testing on the baseline model used is micro, small, and medium business separately. The model baseline in each group is used to define the model parsimony (the measured group is informative enough to explain the model) and that the data fit is significant. Both baseline models have the same four dimensions, namely TOE, TRI, BOI, and DOI, with the same pattern and are fixed and free of loading factors. Baseline models in different groups will integrate into a configurable model that should be similar, but not necessary to be completed similarly [20]. Answers of respondents are inputted with the help of Mplus Ver.7 software. The purpose is to test the baseline model of micro and small and medium enterprises. Table 1 shows the recapitulation of the baseline model output in multigroup.

In Table 1 the model fit test on microbusinesses (group1) based on rule of thumb (Wang and Wang, [20]) indicates that RMSEA $=0.118$ is included in close fit, $90 \% \mathrm{CI}=(0.112,0.124)$ is included in the fair / not very well fitting model, closed fit test $\mathrm{P}-$ Value $=0,000$, $\mathrm{CFI}=0.463$ including moderate fit and TLI $=0.437$ also including moderate fit, and SRMR 0.117 which shows good fit.

The model suitability test for small businesses (group 2) indicates that RMSEA $=0.139$ is included in close fit, $90 \% \mathrm{CI}=(0.132,0.147)$ including not very wellfitting model, P-Value test $=0,000, \mathrm{CFI}=0.291$ including close category fit and TLI $=0.256$ are also included in the close fit category, and SRMR 0.065 which indicates considered fit. From the results of the two baseline models show that the research model is broadly good, and the model results suggest that the measurement of the model from a theoretical design is good enough in each population between groups, so that it can proceed to statistical tests into measurement invariance.

\section{Measurement Invariance Test}

After conducting a baseline model, invariance measurement with four hierarchical steps is done to ensure that the indicator/item used in the study measure the same theoretical constructs in the micro or small-medium scale business groups or women. In contrast, the comparative measurement invariance testing stages are weak and strong RMSEA $=0.095$ 0.0.06 included in the mediocre fit category, $90 \% \mathrm{CI}=$ 
(0.091, 0.099) included in the well-fitting model category, $\mathrm{P}$-value test $=0,000, \mathrm{CFI}=0.532-0.513$ including marginal fit and TLI $=0.437-0.51$ also included in the marginal fit category and SRMR 0.106-0.18 which shows good fit.

\section{Invariance Structural Test}

Measurement of invariance is a prerequisite for structural invariance testing so that the same theoretical construction can be measured in the same way in various populations/groups, the next step is processing structural invariance data in the Mplus program which consists of 2 stages of structural invariant parameter testing, namely:

\section{Variances Invariance Factor and Covariances Invariance Test}

The structural invariance testing stage is tested simultaneously (variances invariance and covariances invariance). The purpose of this test is to examine whether the relationship between the factors studied remains unchanged in different or changing populartions. First, the results are compared to the configured (pattern) invariance model. The changes in the model antara2, between the invariance factor (pattern) model $(5818,073)$ and the weak measurement invariance model $(5363,781)$, are not significant. It can be interpreted that the chi-square model in the covariance variance factor model is greater than the chi-square model in the configure model, so it is not statistically significant. The HO in the strict measurement invariance measurement is rejected. It can be ascer tained that there is no difference, or it is permanent in each group. We conclude that there is no invariance across groups. Invariant factor testing is done to test the average difference factor between groups.

Table 2. Result on goodness of fit structural model test

\begin{tabular}{llr}
\hline \multicolumn{2}{c}{ Criteria } & $\begin{array}{r}\text { Fit information model } \\
\text { Structural model }\end{array}$ \\
\hline Chi square test of & Value & 3103.41 \\
model fit & $\begin{array}{l}\text { Degree of } \\
\text { freedom }\end{array}$ & 2336.00 \\
& P-value & 0.00 \\
RMSEA & Estimate & 0.047 \\
& 90\% C.I & [0.042; 0.051$]$ \\
CFI/TLI & Prob RMSEA & 0.886 \\
& CFI & 0.524 \\
Chi square test of & TLI & 0.521 \\
model fit for the & Delue & 3964.477 \\
baseline model & freedom & 2352 \\
& P-value & 0.000 \\
SRMR & Value & 0.106 \\
\hline
\end{tabular}

The result shows the means factor is not significantly different between the two samples in the micro and small business groups. DOI, TOE, TRI, or BOI did not measure if the effect of variables is higher for one group, but the same for all groups.

\section{Structural Test Model Analysis}

After testing the structural path coefficients' invariantce across groups, the test can proceed to the structural data analysis model processing. The output structural model analysis and model fit information available in Table 2.

The model suitability is quite good, with RMSEA = 0.047 from the test. It is also included in the close fit category, $90 \% \mathrm{CI}=(0.042,0.051)$, so the model has very well-fitting with P-value test $=0.886$ (Close Fit). Therefore, it cannot reject H0, which means there are no differences in the structural models' parameters for different populations. The model categorized as marginal fit with $\mathrm{CFI}=0.524, \mathrm{TLI}=0.521$ but $\mathrm{SRMR}$ 0.106 shows good fit. Based on these results, the intergroup research model analyzed simultaneously is more fit when compared to the baseline model, which is analyzed separately between groups. It can be identified that there are no different parameters in the structural model for different populations.

Based on the structural model analysis results, there are no different parameters in measuring the model in micro and small business groups. It can be evaluated in the multi-group structural models of micro business groups, which explained in Table 3.

In Table 4. The micro-scale (group 1) organizational, environmental, and technological, managerial decisions (TOE) can be seen in the benefits of the technology in the industrial era 4.0. BOI, in the era of industrial 4.0, did not have a significant influence. The insignificant result indicated that on the scale of micro business groups, organizational readiness based on technology, organization, and environment (TOE) Framework did not feel the benefits of industry 4.0, such as gathering information, increasing productivity, easy access to technology. This result is not inline to [16]. This phenomenon can occur because, for the scale of micro-businesses that primarily survive in competition, MSMEs have weaknesses in managerial and technological capabilities, as stated in $[4,7,9,10])$.

Table 3. Analysis path on the model based on micro enterprise scale (Group 1)

\begin{tabular}{cccccc}
\hline $\begin{array}{c}\text { Hypo } \\
\text { thesis }\end{array}$ & Path & Est & P-Value & Effect & Sig value \\
\hline 1 & TOE $\rightarrow$ BOI & -0.058 & 0.420 & - & Not Sig \\
2 & TRI $\rightarrow$ BOI & 0.029 & 0.620 & + & Not Sig. \\
3 & TOE $\rightarrow$ DOI & 0.051 & 0.076 & + & Sig \\
4 & TRI $\rightarrow$ DOI & -0.065 & 0.099 & - & Sig \\
\hline
\end{tabular}


Table 4. Analysis Path on Model Based on Small and Medium Enterprise Scale (Group 2)

\begin{tabular}{ccrccc}
\hline $\begin{array}{c}\text { Hypo } \\
\text { thesis }\end{array}$ & Path & Est & P-value & Effect & $\begin{array}{c}\text { Sig } \\
\text { Value }\end{array}$ \\
\hline 1 & TOE $\rightarrow$ BOI & -0.258 & 0.000 & - & Sig \\
2 & TRI $\rightarrow$ BOI & 0.110 & 0.026 & + & Sig \\
3 & TOE $\rightarrow$ DOI & 0.051 & 0.076 & + & Sig \\
4 & TRI $\rightarrow$ DOI & -0.065 & 0.099 & - & Sig \\
\hline
\end{tabular}

Thus, at the micro enterprise-scale (group 1) in order to be able to feel the benefits of industry 4.0 technology, training in managing SMEs is needed. Additionally, the top management should support the organization not only in using social media but also using the cloud, fintech, big data, and others.

The results show that technological readiness (TRI) does not significantly influence the positive benefits of industry 4.0 (BOI), which is not inline to [12] on SMEs' readiness to successfully adopt, use, and benefit from technologies. Even without readiness in technologies (TRI), microscale enterprise still gets the benefits of Industry 4.0 era for the productivity of their businesses from using e-marketplaces and social media.

Also, Table 3 indicates a positive influence on managerial decisions (TOE) on the use of technology pillars as industry dimensions 4.0 (DOI) this is in accordance with [11,12], as well as a significantly (-0.065) adverse effect on technology readiness (TRI) on the use of pillars technology as an industrial dimension 4.0 (DOI) so that without the readiness technology use, the micro-scale group continues to use technology pillars (DOI) in the form of social media, cloud computing, mobile computing, digitization, and big data. In line with [4] shows the number of MSMEs, which means an increase in the readiness of MSME owners in adopting technology, does not prioritize the use of technology in developing their businesses. Table 4 explains the evaluation of the structural model based on output for the small and medium enterprise.

In Table 4. It can be seen in the small and medium scale business (group 2) managerial decisions in organizational, environmental, and technological (TOE) in the industrial era 4.0 significantly influence the benefits of the presence of technology in the industrial era 4.0. Adverse effects on BOI $(-0,258)$ can indicate the reverse conditions of micro-scale groups so that they can feel the benefits of industry 4.0 without managerial decisions in business readiness in the industrial era 4.0. It is different from the hypotheses that have been predicted. Fathian et al. [12] show the need for infrastructure support for SMEs in Iran applies the TOE framework to get benefit from ICT technology (BOI). So that it can contribute more to economic development, but this research provides a different condition of predicted conditions, so that SMEs in Kab.
Karawang does not need infrastructure support in terms of technology, organization, or environment (TOE) framework to get the benefits of technology (BOI). The higher the managerial decision support in TOE, the lower the perceived benefits. This research shows the benefits of industry 4.0 technology perceived by respondents as information gatherers and customer feedback. The opposite direction in statistical analysis indicates an increase in the managerial readiness by the TOE does not increase information gathering as one of the benefits of industry 4.0 technology. The result is inline with research [21] which has the opposite direction results in the TOE framework, the environment of benefits, especially in gathering information, Arnold et al. [21] show that there is no effect of increasing information despite the increase in environmental factors. Unlike micro-scale business groups feel the benefits of industrial era 4.0 (BOI) is significantly affected by technology readiness (TRI). Thus, small and medium scale groups indicate it without TOE readiness, but TRI, which influences the benefits of the industrial era 4.0 for their business productivity.

Table 5 indicates a positive influence on managerial decisions (TOE) on the use of technology pillars as industry dimensions 4.0. The DOI measured in this study has a significantly negative effect on technology readiness (TRI) on the use of pillars technology as an industrial dimension 4.0 (DOI). Without technological readiness, small and medium scale business groups continue to use technology pillars (DOI) in the form of social media, cloud computing, mobile computing, digitization, and big data. Other research [14] gives a different statement that readiness in adopting technology (TRI) will most likely influence the behavior of the use of advanced technology, a decrease in technological readiness can occur due to old technology being replaced by new technology.

Table 5 shows the sum of the total score to categorize Kab. Karawang SMEs based on the level of readiness in the industrial era 4.0 with an overall TRI score of 3.63, which means based on the level of Technology Readiness Index (TRI), Kab. Karawang SMEs have a level of readiness, which was high in the industrial era 4.0. From the $300 \mathrm{Kab}$ Karawang SMEs used as respondents, 234 SMEs (78\% of MSMEs) have used industry 4.0 technology pillars to conduct their business.

Table 5. TRI Score

\begin{tabular}{ll}
\hline TRI Variable & Score \\
\hline Optimisme & 1,00 \\
Innovativeness & 0,89 \\
Discomport & 0,85 \\
Insecurity & 0,91 \\
\hline Total TRI Score & 3,65 \\
\hline
\end{tabular}


It indicated that they are ready to accept, implement, and use them. Dimensions of optimism (optimism) contributed the most significant TRI assessment to the readiness of the Kab. Karawang SMEs with a total score of 1.00, meaning that the Kab. Karawang SMEs players have an optimistic view of the industry 4.0 era and believe it will provide control, increase performance, and efficiency in life. The discomfort dimension has the lowest contribution with a total score of 0.85 , which means that the Karawang regency SMEs tend to feel uncomfortable about using technology in the categories that try and explore in the industrial era 4.0 in their business. Although the knowledge of the type of Industry 4.0 technology still needs to be increased.

\section{Conclusion}

Kab. Karawang SMEs can be said to be ready with a TRI score of 3.65 in facing the Industrial 4.0 era because there are many young SMEs who can adapt and capture opportunities for current developments and market demand. Still, the many SME actors who do not follow the SMEs community are of particular concern, so efforts are needed different approaches in developing the SMEs industry in Kab Karawang so that coaching can be done. Thus, further research can explore the readiness of SMEs factors in Karawang Regency differently or not from the SMEs scale business group as well as test the hypotheses in the research model to determine the effect of SMEs' readiness in Industry 4.0. It can be used as a guide for stakeholders to conduct MSME coaching and improve knowledge in effectively developing Industry 4.0 skills. In the micro-scale business (group 1), the influencing factors are organizational readiness (TOE), and technology readiness (TRI) in using Industry 4.0 technology (DOI). This condition is quite reasonable considering the group 1 is a micro-scale business with readiness managerially increased in technology, organizational and environmental (TOE) and increased readiness for technology adoption (TRI) will increase the use of industry technology 4.0 (DOI). Still, the usefulness of technology use in industry 4.0 does not increase. It indicates the need for assistance in micro-scale business, such as to conduct workshops to advance the understanding of any technological application features in the era of industry 4.0 so that it can increase the use of micro-scale business and developing their business.

Whereas in small and medium scale business (group 2), managerial (TOE) and technological readiness (TRI) factors influence the use of technology (DOI) and also feel the benefits of the technology used in the industrial era 4.0 (BOI). The asset and profit on group 2 or middle category of business scale are qualified for managerial to adopt technology in the industry 4.0 era. Group 2 realizes the increasing use of technology in the industry 4.0 era will increase competitiveness and excellent benefits in developing its business.

Based on the results of this study, local government should foster and educate MSMEs tailor-made based on business scale groups and their needs so that impact can be on target, coaching is needed in the form of: (1) Guidance on micro-scale business groups, emphasizing managerial aspects in addition to technological aspects to be more competitive and facing competition in the industrial era 4.0 (2). Coaching in small and medium scale business groups, with superior human resource training in organizational readiness, explores the benefits of technology in companies in the industrial era 4.0.

\section{Acknowledgement}

This research is funded by Kementerian, Riset, Teknologi, dan Pendidikan Tinggi Republik Indonesia and Universitas Singaperbangsa Karawang, Hibah Penelitian Dosen Pemula (PDP) 2019.

\section{References}

1. Vaidya, S., Ambad, P., and Bhosle, S., Industry 4.0 - A Glimpse, Procedia Manufacturing, 20, 2018, pp. 233-238

2. Qin, J., Liu, Y., and Grosvenor, R., A Categorical Framework of Manufacturing for Industry 4.0 and beyond, Procedia CIRP, 52, 2016, pp. 173178.

3. Satya, V. E., Strategi Indonesia menghadapi Industri 4.0, Info Singkat, 10(9), 2018, pp. 19-24.

4. Nugroho, M. A., Impact of Government Support and Competitor Pressure on the Readiness of SMEs in Indonesia in Adopting the Information Technology, Procedia Computer Science, 72, 2015, pp. 102-111.

5. KUMKM, W., Penguatan Umkm untuk Pertumbuhan Ekonomi yang Berkualitas, Warta KUMKM, Jakarta, 2016.

6. Sari, R. P., and Santoso, D. T., Pengembangan Model Kesiapan UMKM di Era Revolusi Industri 4.0, Jurnal Media Teknik dan Sistem Industri, 3(1), 2019, pp. 37-42.

7. Faller, C., and Feldmüller, D., Industry 4.0 Learning Factory for Regional SMEs, Procedia CIRP, 32, 2015, pp. 88-91.

8. Suci, Y. R., Perkembangan UMKM (Usaha Mikro Kecil dan Menengah) di Indonesia, Cano Ekonomos, 6(1), 2017, pp. 51-58.

9. Issa, A., Lucke, D., and Bauernhansl, T., Mobilizing SMEs towards Industrie 4.0-Enabled Smart Products, Procedia CIRP, 63, 2017, pp. 670-674. 
10. Taryadi, Pengukuran Tingkat Kesiapan Adopsi E-Marketplace bagi UMKM Batik dengan Model E-Readiness, Seminar Nasional Teknologi Informasi dan Komunikasi, 2016, pp. 162-168.

11. Aboelmaged, M. G., Predicting e-Readiness at Firm-level: An Analysis of Technological, Organizational and Environmental (TOE) Effects on eMaintenance Readiness in Manufacturing Firms, International Journal of Information Management, 34(5), 2014, pp. 639-651.

12. Fathian, M., Akhavan, P., and Hoorali, M., eReadiness Assessment of Non-profit ICT SMEs in a Developing Country: The Case of Iran, Technovation, 28(9), 2008, pp. 578-590.

13. Achjari, D., Abdillah, W., Suryaningsum, S., and Suratman, S., Kesiapan Usaha Mikro, Kecil dan Menengah Industri Kreatif untuk Mengadopsi Teknologi Informasi, Jurnal Akuntansi dan Auditing Indonesia, 15(2), 2011, pp. 143-160.

14. Parasuraman, A., and Colby, C. L., An Updated and Streamlined Technology Readiness Index: TRI 2.0, Journal of Service Research, 18(1), 2015, pp. 59-74.

15. Tiago, M. T. P. M. B., and Veríssimo, J. M. C., Digital Marketing and Social Media: Why Bother?, Business Horizons, 57(6), 2014, pp. 703708.

16. Oesterreich, T. D., and Teuteberg, F., Understanding the Implications of Digitisation and Automation in the Context of Industry 4.0: A Triangulation Approach and Elements of a Research Agenda for the Construction Industry, Computers in Industry, 83, 2016, pp. 121-139.
17. Schumacher, A., Erol, S., and Sihn, W., A Maturity Model for Assessing Industry 4.0 Readiness and Maturity of Manufacturing Enterprises, Procedia Cirp, 52(1), 2016, pp. 161-166.

18. LPPM Universitas Singaperbangsa Karawang, Rencana Strategis Pembangunan Koperasi Usaha Mikro, Kecil dan Menengah Kabupaten Karawang Tahun 2016-2021, LPPM Universitas Singaperbangsa Karawang, Karawang, 2015.

19. Sekaran, U., and Bougie, R., Research Methods for Business: A Skill Building Approach, John Wiley \& Sons, West-Sussex, 2009.

20. Wang, J., and Wang, X., Structural Equation Modeling: Methods and Applications, John Wiley \& Sons, West-Sussex, 2012.

21. Arnold, C., Veile, J., and Voigt, K. I., What Drives Industry 4.0 Adoption? An Examination of Technological, Organizational, and Environmental Determinants, International Association for Management of Technology (IAMOT), 2018, pp. 1-19.

22. Hassan, H., Nasir, M.H.M., Khairudin, M. and Adon, I., Factors Influencing Cloud Computing Adoption in Small Medium Enterprises, Journal of ICT, 16 (1), 2017, pp. 21-41.

23. Alemeye, F., and Getahun, F., Cloud Readiness Assessment Framework and Recommendation System, AFRICON, 2015, pp. 1-5.

24. Rosmayanti, H., Aryadita, H., and Herlambang, A. D., Analisis Penerimaan Teknologi Cloud Storage Menggunakan Technology Readiness Acceptance Model (TRAM) pada Badan Eksekutif Mahasiswa Institut Teknologi Sepuluh Nopember, Jurnal Pengembangan Teknologi Informasi dan Ilmu Komputer, 2(10), 2018, pp.3632-3639. 
Appendix 1: Operational variables

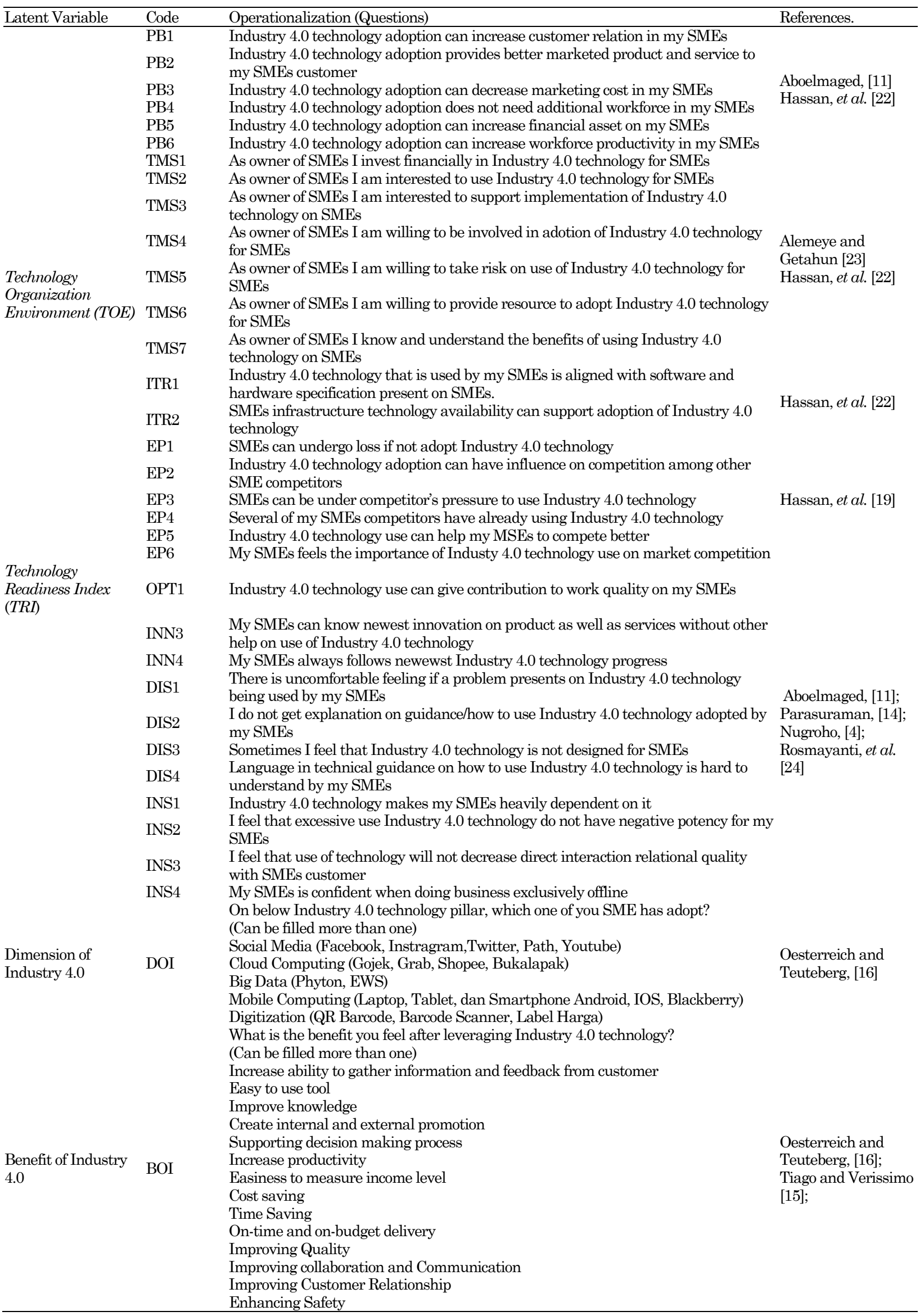

